(classes), games, modeling of pedagogical situations, etc.). It was proved that spontaneity, creativity and creativity are the most important components of the art technology.

It was outlined trends in the introduction of art technology of fairy-tale therapy as a method in which a fairy-tale form is used for the integration of personality, the development of its creative abilities, and the improvement of interaction with the surrounding world. It was characterized the types of fairy tales, that are used in fairy tale therapy, with the respect to the specifics of their application in the creative self-realization of the personality.

Key words: art, personality, art therapy, art technology, creativity, fairy tale therapy, types of tales, creative activity, correction.

УДК 159.9:37.23

O. В. IBAHЮTA

\title{
ДИНАМІКА ФОРМУВАННЯ ТА РОЗВИТКУ ОПЕРАЦІОНАЛЬНИХ ХАРАКТЕРИСТИК ВІЗУАЛЬНОГО МИСЛЕННЯ В ПІДЛІТКОВОМУ ВІЦІ
}

У статті подано результати констатуючого експерименту, описано комплекс методів, які дозволяють діагностувати рівень розвитку операціональної сфери візуального мислення. Розглянуто динаміку формування та розвитку операціональних характеристик візуального мислення в підлітковому віці. Аналізуються міжструктурні зв'язки даних, отриманих за методикою Равена, що дозволяє зробити висновок про взаємозв'язок операціональних складових візуального мислення підлітків, щэо є надзвичайно важливим для розробки програми розвитку візуального мислення.

Ключові слова: візуальне мислення, операчіональна сфера візуального мислення, динаміка показників методики Равена, кореляційні зв'язки.

В статье представлень результаты констатирующего эксперимента, описано комплекс методов, позволяющих диагностировать уровень развития операчиональной сферы визуального мылиления. Рассмотрена динамика формирования и развития операциональных характеристик визуального мылиения в подростковом возрасте. Анализируются межструктурные связи данных, полученных по методике Равена, что позволяет сделать вывод о взаимосвязи операџиональных составляющих визуального мышления подростков, что является чрезвычайно важным для разработки программы развития визуального мышления.

Ключевые слова: визуальное мышление, операчиональная сфера визуального мышления, динамика показателей методики Равена, корреляционные связи.

Постановка проблеми. Необхідність впровадження нових ефективних технологій, які базуються на візуальних засобах кодування та передачі інформації, робить дослідження візуального мислення, а також пошук і розробку дійових засобів його розвитку одним із важливих завдань сучасної психологічної науки і педагогічної практики. Актуальність вивчення візуального мислення як специфічного виду розумової діяльності також визначається тим, що цей процес займає особливе місце в інтелектуальному і творчому розвитку особистості і $є$ найменш дослідженим з усіх інтелектуальних процесів як у вітчизняній, так і в зарубіжній педагогічній науці.

Аналіз останніх досліджень і публікацій. У вітчизняній психолого-педагогічній науці дослідження візуального мислення представлено: вивченням механізмів та закономірностей цього процесу в умовах вирішення ергономічних задач в інженерній психології (В. М. Гордон, В. ІІ .Зінченко, В. М. Муніпов); дослідженням його механізмів як складної функціональної системи операцій (Б. І. Безпалов); визначенням візуальної мови опису способів вирішення геометричних задач (І. М. Арієвич, В. В. Пєтухов); вивченням особливостей просторового мислення як окремого виду візуального мислення (I. Я. Каплунович [3], I. С. Якиманська); визначенням ролі візуалізації в процесі вирішення 
творчих задач у конструкторській діяльності (В. О. Моляко); дослідженням особливостей трансформації візуального образу в художньо-графічній діяльності (С. М. Симоненко[4], О.В. Іванюта, С.М. Симоненко [2]).

Найбільш поширеним у вітчизняній психологічній науці є визначення візуального мислення як специфічного виду інтелектуальної діяльності, змістом якої є оперування та маніпулювання зоровими (візуальними) образами, а результатом - створення нових образів, що несуть змістовне навантаження й роблять значення видимим.

Формулювання цілей статті. Метою дослідження $\epsilon$ розкриття динаміки та особливостей операціональної сфери візуального мислення підлітків з метою подальшої розробки цілеспрямованої програми його розвитку. Для досягнення мети вирішуються завдання: дослідження за допомогою спеціально підібраного комплексу методик закономірностей розвитку візуального мислення в підлітковому віці.

Виклад основного матеріалу дослідження. Поряд 3 іншими методиками для дослідження візуального мислення підлітків нами була використана шкала прогресивних матриць Равена [1]. Дана методика спирається на достатньо розроблену теоретичну концепцію, зокрема, ряд побудов гештальтпсихології з теорії перцепції форм. Згідно даної теорії, кожне завдання може розглядатися як єдине ціле, що складається із сукупності взаємопов'язаних елементів. Вважається, що спочатку здійснюється глобальне оцінювання завдання (матриці), а вже потім відбувається дія систематичної перцепції, за допомогою якої досліджуваний виділяє принцип, закладений при розробці серії. Завершальний етап містить процес включення виділених елементів у цілісний образ, що сприяє визначенню деталі зображення, якої не вистачає.

Методику Равена було використано в нашій роботі 3 метою дослідження операціональної сфери візуального мислення підлітків. Вибір цієї методики для вивчення операціонарьних компонентів візуального мислення зумовлений тим, що даний тест було створено з метою дослідження перцептивно-мисленнєвої сфери, а саме продуктивної функції невербального інтелекту. У нашій роботі застосування даної методики дає можливість дослідити етапи формування образу, а також визначити міру оволодіння набором операцій, необхідних для побудови шуканого образу.

Використаний нами непарний варіант методики Равена містить 30 чорно-білих матриць 3 пропущеним елементом композиції. Завдання тесту згруповані за п'ятьма серіями (A, B, C, D, Е). Кожна серія складається з 6 матриць, розташованих послідовно в міру ускладнення завдання. Принцип прогресивності, закладений авторами тесту, реалізується шляхом поступового зростання складності завдань від серії до серії. Таким чином, виконання попередніх завдань одночасно $€$ підготовкою до розв'язання наступних. Кожна серія побудована за певним принципом, який відображає окремі операціональні етапи аналітикосинтетичної діяльності візуального мислення. Процедура тестування передбачала вибір досліджуваним потрібного елемента матриці 3-поміж запропонованих 6-8 варіантів. Підрахунок результативності тестування здійснювався методом обчислення кількості набраних балів (за кожну правильну відповідь нараховувався 1 бал) по кожній серії окремо, а також загальної суми оцінок по тесту.

У дослідженні за методикою Равена брали участь 6 груп підлітків віком від 10 до 15 років. Кожна група включала по 30 досліджуваних відповідного віку. Всього за даною методикою протестовано 180 підлітків. Заповнено й зареєстровано 180 протоколів дослідження; зроблено кількісний та якісний аналіз отриманих даних.

За методикою Равена критеріями оцінки характеристик аналітико-синтетичних процесів візуального мислення підлітків виступають такі показники:

1. Диференціювання основних елементів структури, з'ясування зв'язків між ними та ідентифікація відсутньої частини.

2. Встановлення аналогії між парами фігур за принципом поступового диференціювання.

3. Перегрупування елементів фігури на базі аналізу візуальної інформації.

4. Конструювання нового візуального образу за допомогою логічних пошуків. 
Розглянемо успішність виконання завдань методики за кожною серією.

Завдання серії А базуються на пошуку зв'язку в структурі матриці за принципом відповідності фігури загальному фону. При розв'язанні цієї серії завдань досліджуваному потрібно доповнити зображення тією частиною, якої не вистачає на даному фоні. У процесі роботи з матрицями серії А реалізуються такі операціональні характеристики продуктивного візуального мислення, як здатність до диференціювання основних елементів графічної структури, встановлення зв'язків між ними, ідентифікація відсутніх частин та їх співставлення із запропонованими зразками. Оцінки успішності виконання завдань даної серії досліджуваними різного віку подані у таблиці 1.

Таблиця 1

Оцінка виконання тестових завдань методики Равена (Серія А)

\begin{tabular}{|c|c|c|c|c|c|c|}
\hline \multirow[t]{2}{*}{$\begin{array}{l}\text { Статистичні } \\
\text { показники }\end{array}$} & \multicolumn{6}{|c|}{$\begin{array}{c}\text { Кількісні показники успішності виконання завдань респондентами } \\
\text { різних вікових підгруп }\end{array}$} \\
\hline & 10 років & 11 років & 12 років & 13 років & 14 років & 15 років \\
\hline$\overline{\mathrm{X}}$ & 5,13 & 5,20 & 5,20 & 5,53 & 5,60 & 5,83 \\
\hline$\sigma$ & 1,01 & 1,03 & 0,89 & 0,82 & 0,72 & 0,46 \\
\hline
\end{tabular}

Дані, подані в табл. 1, виявляють високу успішність виконання завдань серії А підлітками всіх вікових груп, які приймали участь у дослідженні. У кожній групі виконано щонайменше по 5 завдань із 6 запропонованих). Динаміка оцінок подана у таблиці 2.

Таблиця 2

Значущість відмінностей показників методики Равена. (Серія А)

\begin{tabular}{|c|c|c|c|c|c|c|}
\hline \multirow{2}{*}{ Показники } & \multicolumn{5}{|c|}{ Співставлення показників різних вікових підгруп } \\
\cline { 2 - 7 } & $10 / 11$ p. & $11 / 12$ p. & $12 / 13$ p. & $13 / 14 \mathrm{p}$. & $14 / 15 \mathrm{p}$. & $10 / 15 \mathrm{p}$. \\
\hline $\mathrm{t}$ & 0 & 1,13 & 5,17 & 3,18 & 8,97 & 15,00 \\
\hline $\begin{array}{l}\text { підвищення } \\
\text { оцінок }\end{array}$ & незнач. & незнач. & знач. & знач. & знач. & знач. \\
\hline & & \multicolumn{7}{|c|}{$\mathrm{t}_{\text {кр. }}=2,00 ; \mathrm{p}=0,05$} \\
\hline
\end{tabular}

Отже, можна зробити висновок, що вміння співставляти фігуру та фон за принципом структурної відповідності є достатньо сформованим вже на початок підліткового віку. Аналіз різниці показників результативності розв'язання завдань серії А за критерієм Стьюдента виявив, що відмінність між оцінками, отриманими досліджуваними 11 та 12 років, $\epsilon$ статистично не значущою (див. табл. 2). Співставлення оцінок інших вікових груп досліджуваних показало статистичну значущість зростання показників. Таким чином, протягом досліджуваного нами вікового періоду відбувається поступовий розвиток вище зазначених операціональних структур візуального мислення. Якщо у віці 10 років підлітки вже володіють комплексом мисленнєвих операцій, необхідних для встановлення ідентичності фігури i фону, то подальший розвиток аналітико-синтетичної функції візуального мислення полягає в розширенні здатності до аналізу більш складних графічних структур, які являють собою організовану сукупність різних елементів і вивчення котрих вимагає включення до операціонального ланцюжка додаткових мисленнєвих етапів.

Серія В побудована за принципом встановлення аналогії між парами фігур та визначення закономірностей їх взаєморозташування. У процесі роботи з матрицями цієї серії підліток реалізує даний принцип шляхом поступової диференціації елементів фігур. Показники успішності виконання завдань серії В представлені в таблиці 3, а їх динаміка - у таблиці 4. Аналіз показників (див. табл. 3) показує, що відносно даних операцій візуального мислення значно чіткіше простежуються онтогенетичні закономірності розвитку.

Якщо на початку підліткового віку успішність виконання завдань цієї серії становить у середньому 3,77 бала (10 років), то під кінець досліджуваного періоду вона зростає до 5,67 бала (15 років). 
Оцінка виконання тестових завдань методики Равена (Серія В)

\begin{tabular}{|c|c|c|c|c|c|c|}
\hline \multirow{2}{*}{$\begin{array}{c}\text { Статистичні } \\
\text { показники }\end{array}$} & \multicolumn{5}{|c|}{ Кількісні показники успішності виконання завдань респондентами } \\
& 10 років & 11 років & 12 років & 13 років & 14 років & 15 років \\
\cline { 2 - 7 } & 3,77 & 3,90 & 4,47 & 5,23 & 5,33 & 5,67 \\
\hline$\overline{\mathrm{x}}$ & 1,48 & 1,18 & 1,20 & 0,86 & 0,80 & 0,66 \\
\hline$\sigma$ & \multicolumn{7}{|c|}{}
\end{tabular}

Таблиця 4

Значущість відмінностей показників методики Равена (Серія В)

\begin{tabular}{|l|c|c|c|c|c|c|}
\hline \multirow{2}{*}{ Показники } & \multicolumn{5}{|c|}{ Співставлення показників різних вікових підгруп } \\
\cline { 2 - 7 } & $10 / 11 \mathrm{p}$. & $11 / 12 \mathrm{p}$. & $12 / 13 \mathrm{p}$. & $13 / 14 \mathrm{p}$. & $14 / 15 \mathrm{p}$. & $10 / 15 \mathrm{p}$. \\
\hline $\mathrm{t}$ & 1,09 & 3,75 & 5,80 & 2,04 & 8,72 & 21,59 \\
\hline $\begin{array}{l}\text { підвищення } \\
\text { оцінок }\end{array}$ & незнач. & знач. & знач. & знач. & знач. & знач. \\
\hline \multicolumn{7}{|c|}{} \\
\end{tabular}

Перевірка відмінностей оцінок різних вікових груп досліджуваних виявила (див. табл. 4), що лише в роботах підлітків 10-11 років різниця показників є статистично незначущою. Слід окремо відзначити результативність розв'язання завдань серії В, яку показали підлітки 12 років. Розрив між оцінками підлітків 10 та 12 років становить 0,70 бала, між 12 та 13 років - 0,76 бала, у той час як між показниками інших вікових груп він становить від 0,10 до 0,34 бала. Значне підвищення різниці відмінності оцінок, підтверджене перевіркою за критерієм Стьюдента, спостерігається між 12 та 13 роками. Такий розрив між показниками даних вікових груп свідчить, що у віці 12 років починається, а в 13 років стає особливо інтенсивним розвиток операцій візуального мислення, які забезпечують трансформацію графічних образів за правилами аналогії та симетрії.

В основу завдань серії С покладено принцип поступового розвитку фігур всередині матриці шляхом горизонтального та вертикального збагачення за допомогою нових елементів. Розглянемо показники виконання завдань серії $\mathrm{C}$ та їх динаміку (див. табл. 5 i табл. 6).

Таблиця 5

Оцінка виконання тестових завдань методики Равена (Серія С)

\begin{tabular}{|c|c|c|c|c|c|c|}
\hline \multirow{2}{*}{$\begin{array}{c}\text { Статистичні } \\
\text { показники }\end{array}$} & \multicolumn{5}{|c|}{ Кількісні показники успішності виконання завдань респондентами } \\
& \multicolumn{7}{|c|}{ різних вікових підгруп } \\
\cline { 2 - 7 } & 10 років & 11 років & 12 років & 13 років & 14 років & 15 років \\
\hline$\overline{\mathrm{x}}$ & 2,87 & 3,23 & 3,67 & 4,60 & 4,97 & 5,17 \\
\hline$\sigma$ & 1,31 & 1,45 & 1,32 & 1,13 & 0,96 & 0,91 \\
\hline
\end{tabular}

Таблиця 6

Значущість відмінностей показників методики Равена (Серія С)

\begin{tabular}{|l|c|c|c|c|c|c|}
\hline \multirow{2}{*}{ Показники } & \multicolumn{5}{|c|}{ Співставлення показників різних вікових підгруп } \\
\cline { 2 - 7 } & $10 / 11 \mathrm{p}$. & $11 / 12 \mathrm{p}$. & $12 / 13 \mathrm{p}$. & $13 / 14 \mathrm{p}$. & $14 / 15 \mathrm{p}$. & $10 / 15 \mathrm{p}$. \\
\hline \multicolumn{1}{|c|}{} & 2,10 & 1,93 & 5,00 & 5,00 & 1,78 & 23,98 \\
\hline $\begin{array}{l}\text { підвищення } \\
\text { оцінок }\end{array}$ & знач. & незнач. & знач. & знач. & незнач. & знач. \\
\hline & & & $\mathrm{t}_{\mathrm{KD} .}=2,00 ; \mathrm{p}=0,05$ & \\
\hline
\end{tabular}

Аналізуючи дані, представлені в таблиці 5, можемо відзначити, що значне підвищення складності завдань порівняно 3 попередніми серіями позначилося на результативності їх виконання досліджуваними молодшого підліткового віку. Так, підлітки 10-11 років змогли виконати лише біля половини запропонованих завдань (отримали 
відповідно по 2,87 та 3,23 бала). Однак в інших групах підлітків спостерігається поступове зростання успішності, і вже в 15 років показник виконання завдань серії С становить 5,17 бала. Перевірка різниці показників за критерієм Стьюдента показала, що статистично значущими є відмінності між оцінками підлітків 10-11, 12-13 років, а також 13 та 14 років (див. табл. 6). Отже, особливо активний розвиток операцій візуального мислення, пов'язаних з складними аналітико-синтетичними процесами, відбувається у віці 12-14 років.

Завдання серії D побудовані за принципом перегрупування фігур у матриці. Для успішного виконання завдань цієї серії досліджуваному потрібно одночасно охопити всю закладену в матриці візуальну інформацію, тому що перегрупування елементів матриці відбувається одночасно як по вертикалі, так і по горизонталі. Оцінки успішності виконання завдань серії D представлені в таблиці 7.

Таблиця 7

\begin{tabular}{|c|c|c|c|c|c|c|}
\hline \multirow{2}{*}{$\begin{array}{c}\text { Статистичні } \\
\text { показники }\end{array}$} & \multicolumn{6}{|c|}{ Кількісні показники успішності виконання завдань респондентами } \\
& \multicolumn{7}{|c|}{ різних вікових підгруп } \\
\cline { 2 - 7 } & 10 років & 11 років & 12 років & 13 років & 14 років & 15 років \\
\hline$\overline{\mathrm{x}}$ & 2,27 & 2,97 & 3,13 & 3,60 & 4,47 & 4,70 \\
\hline$\sigma$ & 1,48 & 1,38 & 1,17 & 1,49 & 1,11 & 1,06 \\
\hline
\end{tabular}

Показники результативності виконання завдань даної серії, як і оцінки, отримані за попередніми серіями, свідчать, що підвищення рівня складності завдань значно впливає на успішність їх виконання. Зниження результативності, зумовлене ускладненням завдань, відзначається на показниках всіх вікових груп досліджуваних (див. табл. 5 і табл. 7).

У результаті аналізу отриманих даних за критерієм Стьюдента було виявлено, що статистично незначущою є різниця тільки між оцінками підлітків 11 та 12 років (див. табл. $8)$.

Таблиця 8

Значущість відмінностей показників методики Равена (Серія D)

\begin{tabular}{|c|c|c|c|c|c|c|}
\hline \multirow{2}{*}{ Показники } & \multicolumn{5}{|c|}{ Співставлення показників різних вікових підгруп } \\
\cline { 2 - 7 } & $10 / 11 \mathrm{p}$. & $11 / 12 \mathrm{p}$. & $12 / 13 \mathrm{p}$. & $13 / 14 \mathrm{p}$. & $14 / 15 \mathrm{p}$. & $10 / 15 \mathrm{p}$. \\
\hline $\mathrm{t}$ & 5,39 & 0,64 & 2,46 & 7,98 & 4,11 & 19,76 \\
\hline $\begin{array}{l}\text { підвищення } \\
\text { оцінок }\end{array}$ & знач. & незнач. & знач. & знач. & знач. & знач. \\
\hline & & \multicolumn{7}{|c|}{$\mathrm{t}_{\mathrm{KD}}=2,00 ; \mathrm{p}=0,05$} & \\
\hline
\end{tabular}

Особливо значна відмінність спостерігається між показниками, отриманими в роботах підлітків 13 та 14 років. На підставі результатів перевірки даних успішності розв'язання завдань серії D можемо стверджувати, що в підлітковому віці відбувається інтенсивне формування складних операціональних структур візуального мислення, особливо активно такі структури розвиваються у віці 13-14 років.

Найважливе значення для оцінки розвитку операціональних можливостей візуального мислення має серія Е. Завдання цієї серії побудовані за принципом складного багатокомпонентного вертикального і горизонтального відображення елементів матриці. Процес розв'язання завдань серії Е потребує здійснення багаторівневого аналізу зображених фігур і мисленнєвого конструювання на основі отриманої інформації потрібної фігури. Якщо для виконання завдань попередніх серій достатньо володіти одним певним методом обробки візуальної інформації, то розв'язання завдань серії Е вимагає складного багатоступеневого застосування різних операцій аналізу й переробки візуальних даних.

Розглянемо показники успішності виконання завдань серії Е (табл. 9), а також їх динаміку (табл. 10). 
Оцінка виконання тестових завдань методики Равена. Серія Е

\begin{tabular}{|c|c|c|c|c|c|c|}
\hline \multirow{2}{*}{$\begin{array}{l}\text { Статистичні } \\
\text { показники }\end{array}$} & \multicolumn{6}{|c|}{ Кількісні показники успішності виконання завдань респондентами } \\
& 10 років & 11 років & 12 років & 13 років & 14 років & 15 років \\
\cline { 2 - 7 } & 10 ровов & 1,30 & 1,37 & 2,07 & 2,77 & 2,90 \\
\hline$\overline{\mathrm{x}}$ & 0,83 & 1,12 & 1,10 & 1,23 & 1,19 & 1,52 \\
\hline$\sigma$ & 0,59 & &
\end{tabular}

Таблиця 10

Значущість відмінностей показників методики Равена. Серія Е

\begin{tabular}{|c|c|c|c|c|c|c|}
\hline \multirow{2}{*}{ Показники } & \multicolumn{5}{|c|}{ Співставлення показників різних вікових підгруп } \\
\cline { 2 - 7 } & $10 / 11 \mathrm{p}$. & $11 / 12 \mathrm{p}$. & $12 / 13 \mathrm{p}$. & $13 / 14 \mathrm{p}$. & $14 / 15 \mathrm{p}$. & $10 / 15 \mathrm{p}$. \\
\hline $\mathrm{t}$ & 6,94 & 0,68 & 6,60 & 8,86 & 1,27 & 22,07 \\
\hline Підвищення оцінок & знач. & незнач. & знач. & знач. & незнач. & знач. \\
& & \multicolumn{6}{|c|}{$\mathrm{V}=2,00 ; \mathrm{p}=0,05$} \\
\hline
\end{tabular}

Однак перевірка різниці показників серії Е в різних вікових групах за критерієм Стьюдента свідчить, що між оцінками підлітків 10 і 11, 12 і 13, 13 і 14 та 10 і 15 років існує статистично значуща відмінність (див. табл. 10). Отже, дані серії Е також підтверджують висновок, що протягом досліджуваного вікового періоду відбувається значний розвиток операціональних можливостей візуального мислення.

Висновки 3 даного дослідження і перспективи подальших розвідок. Таким чином, на підставі здійсненого нами кількісного аналізу даних дослідження візуального мислення, отриманих за допомогою методики Равена, можемо стверджувати, що стабільне зростання показників за кожною серією матриць, яке спостерігається відповідно до вікової диференціації досліджуваних, свідчить про активне розширення аналітико-синтетичних можливостей операціональної сфери візуального мислення в підлітковому віці.

Отримані результати дозволяють в подальшому розкрити зміст програми розвитку візуального мислення у підлітковому віці.

\section{Список використаних джерел}

1. Анастази А. Психологическое тестирование: пер. с англ. / А. Анастази, С. Урбина. - СПб. : Питер, 2007. - 688 с.

2. Іванюта О. В. Розвиток візуального мислення підлітків / О. В. Іванюта, С. М. Симоненко. - Одеса : ПНЦ АПН України, 2003. - 275 с.

3. Каплуновиич И. Я. О некоторых принципах формирования структуры пространственного мышления / И. Я. Каплуновиич // Структуры познавательной деятельности : сб. науч. тр. - Владимир, 1989. - С. 96-107.

4. Симоненко С. М. Психологія візуального мислення: стратегіально-семантичний підхід / С. М. Симоненко. - Одеса : ПНЦ АПН України, 2005. - 320 с.

\section{References}

1. Anastazy A. Psykholohycheskoe testyrovanye: per. s anhl. / A. Anastazy, S. Urbyna. SPb. : Pyter, 2007. - 688 s.

2. Ivaniuta O. V. Rozvytok vizualnoho myslennia pidlitkiv / O. V. Ivaniuta, S. M. Symonenko. - Odesa : PNTs APN Ukrainy, 2003. - 275 s.

3. Kaplunovyych Y. Ya. O nekotorbkh pryntsypakh formyrovanyia strukturb prostranstvennoho mыshlenyia / Y. Ya. Kaplunovyych // Strukturb poznavatelnoi deiatelnosty : sb. nauch. tr. - Vladymyr, 1989. - S. 96-107. 
4. Symonenko S. M. Psykholohiia vizualnoho myslennia: stratehialno-semantychnyi pidkhid / S. M. Symonenko. - Odesa : PNTs APN Ukrainy, 2005. - 320 s.

\section{O. V. Ivaniuta. DYNAMICS OF FORMATION AND DEVELOPMENT OF OPERATIONAL CHARACTERISTICS OF THE TEENAGERS'VISUAL THINKING}

The paper presents the results of ascertaining experiment; the set of methods that allow diagnosing the level of the operational areas of visual thinking development is described. The dynamics of the formation and development of the operational characteristics of adolescence's visual thinking is considered. The structural interrelationships between the data obtained by the Raven's Progressive Matrices are analyzed. This analysis suggests that a correlation between visual thinking operational components of adolescents is essential for developing the program of visual thinking.

Keywords: visual thinking, visual thinking operational sphere, dynamics of Raven's Progressive Matrices indexes, correlations.

\section{УДК: 159.95}

О. В. IВАНЮТА

\section{ВЗАСМОЗВ'ЯЗОК РІЗНИХ ВИДІВ МИСЛЕННЯ ЯК ПСИХОЛОГІЧНА ПРОБЛЕМА}

На основі аналізу науково-дослідних робіт визначається місие та роль візуального мислення в системі мисленнєвої діяльності. 3 цією метою аналізуються різні класифікації видів мислення: розвиток мислення як тріада; розвиток мислення, який розглядає класична психологія; паралельний розвиток різних видів мислення тощя. Візуальне мислення розглядається як найбільш високий рівень розвитку наочних форм мисленнєвої діяльності. В статті зроблено висновок про те, щзо одним із найбільш суттєвих показників сформованого продуктивного мислення є взаємодія наочних і вербально-логічних компонентів при високому рівні розвитку кожного з них.

Ключові слова: мислення, наочно-дійове мислення, образне мислення, наочно-образне мислення, словесно-логічне мисленн, продуктивне мислення, візуальне мислення, креативність, актуалізація образів.

На основании анализа научных исследований определяется место и роль визуального мылиления в системе мыслительной деятельности. $C$ этой иелью анализируются различные классификации видов мышления: развитие мышления как триада; развитие мылиленя, рассматривает классическая психология; параллельное развитие различных видов мышления и тому подобное. Визуальное мышление рассматривается как наиболее высокий уровень развития наглядных форм мыслительной деятельности. В статье сделан вывод о том, что одним из наиболее существенных показателей сформированного продуктивного мышления является взаимодействие наглядных и вербально-логических компонентов при высоком уровне развития каждого из них.

Ключевые слова: мышление, наглядно-действенное мышление, образное мышление, наглядно-образное мышление, словесно-логическое мышление, продуктивное мышление, визуальное мьлиление, креативность, актуализация образов.

Постановка проблеми. Вивчення візуального мислення як специфічного виду розумової діяльності визначається тим, що цей процес займає особливе місце в інтелектуальному і творчому розвитку особистості. Існуюче розмаїття взаємозв'язку різних видів мислення в зарубіжній та вітчизняній психології і ускладнює розробку концептуальних підходів, які б давали можливість конструктивно дослідити механізми та специфіку 